\title{
A 30 Years Treatise of Allergies and Asthma in Saudi Arabia (1989-2019)
}

\author{
Syed M Hasnain ${ }^{1}$ and Abdulrahman Al Frayh ${ }^{2 *}$ \\ ${ }^{1}$ Department of Cell Biology, King Faisal Specialist Hospital and Research Centre, Riyadh, \\ Saudi Arabia \\ ${ }^{2}$ Department of Pediatrics, College of Medicine,King Saud University, Department of Pediatrics, \\ Riyadh, Saudi Arabia
}

ISSN: 2576-9200

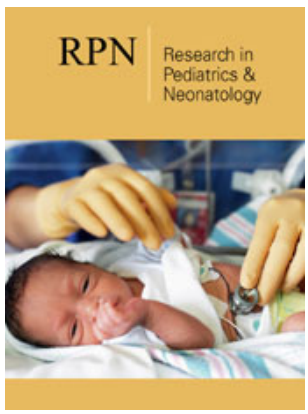

${ }^{* 1}$ Corresponding author: Abdulrahman Al Frayh, College of Medicine,King Saud University, Department of Pediatrics, Riyadh, Saudi Arabia, Riyadh, Saudi Arabia

Submission: 策June 27, 2019

Published: 酸July 03, 2019

Volume 3 - Issue 4

How to cite this article: Syed $\mathrm{M} \mathrm{H}$, Abdulrahman Al F. A 30 Years Treatise of Allergies and Asthma in Saudi Arabia (1989-2019). Res Pediatr Neonatol. 3(4). RPN.000566.2019.

DOI: $10.31031 /$ RPN.2019.03.000566

Copyright@ Abdulrahman Al Frayh, This article is distributed under the terms of the Creative Commons Attribution 4.0 International License, which permits unrestricted use and redistribution provided that the original author and source are credited.

\section{Introduction}

The scientific and clinical investigations, on both prevalence of allergies and asthma and their possible causative factors in Saudi Arabia, have continued since 1989. Primarily, being a desert country, western scientists and physicians did not believe the existence of a high prevalence of asthma and allergic rhinitis in Saudi Arabia, considering it as a non-specific bronchial hyper reactivity rather than an IgE mediated allergic response to local/regional allergens. In the late 80 's, we started our investigation on prevalence of asthma with an internationally designed questionnaire led by Professor JD Wilson, that time Professor of Clinical Immunology at King Saud University, Riyadh, Saudi Arabia. At the same time, we started indoor and outdoor aeroallergens monitoring program to evaluate the presence and role of various allergens presents in the environment. Our earlier findings were published [115], followed by many other investigators in the country. We continued our investigation and compared the prevalence data from 9 cities which showed an increasing pattern of asthma and allergic rhinitis nationally (Figure 1).

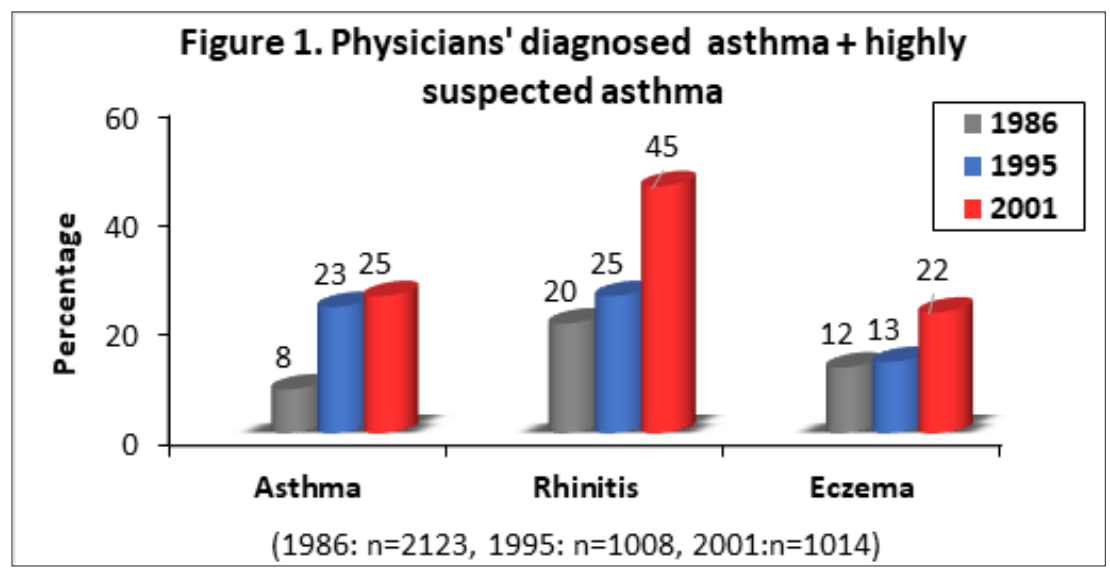

Figure 1.

A comparison with the available data from different countries (different methods used), Saudi Arabia stood in the middle of the world, close to western Europe (Figure 2). A number of investigations, followed since the early publication in 1989, have confirmed that there is an increase in IgE mediated respiratory allergic diseases in almost all regions of Saudi Arabia.

The causative factors investigated have a great deal of regional variations. For example, airborne pollen grains, in some cases, are different (Salsola imbricata) from the species known to cause allergies in the United States or the European continent (Salsola kali). Likewise, a few potent allergens, e.g. Ragweed (Ambrosia artemisiifolia) is not found in Saudi Arabia. The authors have therefore decided to summarize their own work along with other investigators within Saudi Arabia or with regional and international collaboration, as a treatise of asthma and allergies in Saudi Arabia covering a period of research and investigation from 1989 to 2019. The treatise will include all aspects related to allergic diseases. The areas we intend to cover may include 1) Bronchial asthma, 2) Allergic Rhinitis (Hay Fever), 3) Atopic Eczema, 
4) Conjunctivitis, 5) Heredity of Asthma, 6) Wheezy Bronchitis, 7) Smoking and Asthma, 8) School and Asthma, 9) Sleep and Asthma, 10) Rain induced asthma 11) Indoor Allergens and Asthma, 12) High Altitude and Asthma, 13) Diet and Asthma, 14) Pet and Asthma, 15) Allergic bronchopulmonary mycosis and Asthma, 16) Allergic bronchopulmonary aspergillosis and Asthma, 17) Prosopis juliflora antigen and asthma, 18) Urban/Rural Areas in Saudi Arabia and
Asthma, 19) Obesity and Asthma, etc. Our recent studies published [16-24] present interesting data on indoor allergens both in coastal and non-coastal cities along with patients and control homes. Most of these data are available online however, a review to include all these will benefit not only the clinicians and scientists but allergy and asthma patients as well.

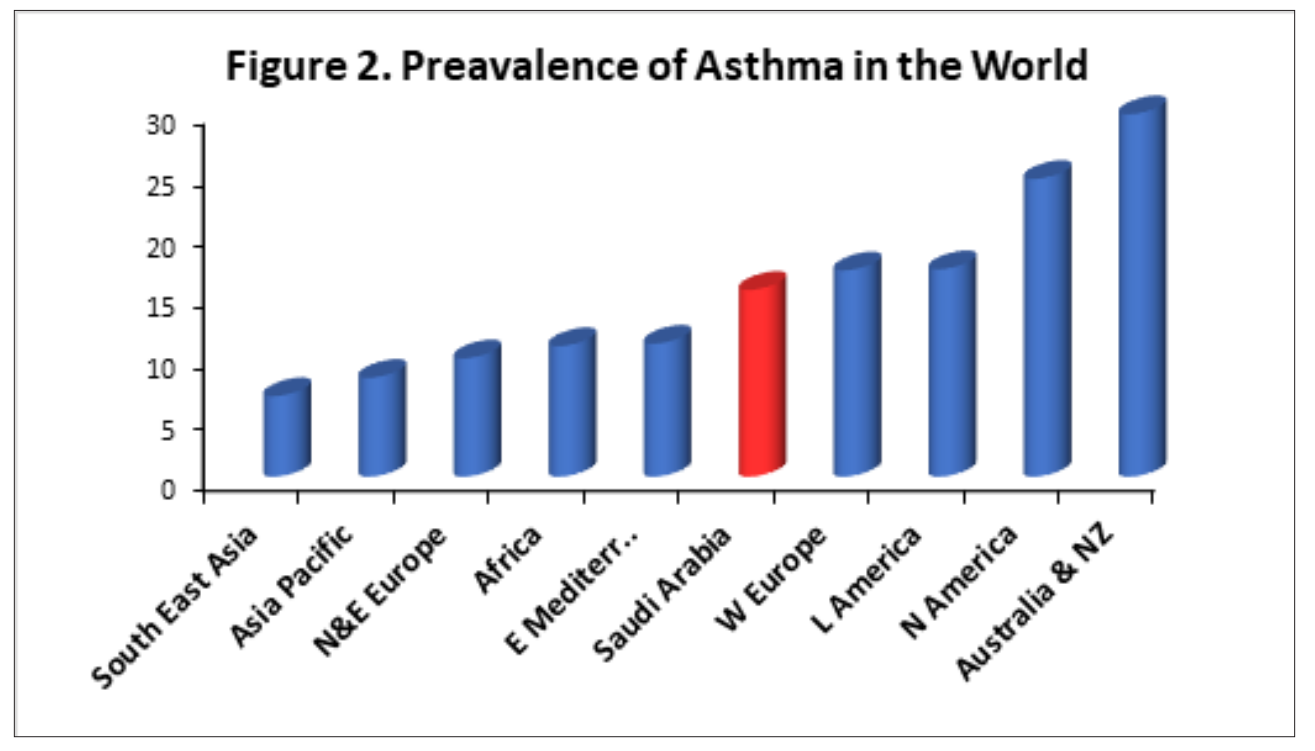

Figure 2.

\section{References}

1. Frayh AR, Hasnain SM, Wilson JD (1987) Aero-allergological research in three cities of Saudi Arabia. International Aerobiology Newsletter, BiAnnual Publication of the International Association for Aerobiology, pp. 20-21.

2. Hasnain SM, Frayh AR, Thorogood R, Harfi HA, Wilson JD (1989) Seasonal periodicities of fungal allergens in the atmosphere of riyadh. Annals of Saudi Medicine 9(4): 337-343.

3. Frayh AR, Hasnain SM (1989) Indoor allergens and atopic response in children in Saudi Arabia. The European Respiratory Journal, p. 646.

4. Frayh, Hasnain SM (1989) Prevalence of asthma in Saudi Arabia. European Annals of Allergy and Clinical Immunology, p. 16.

5. Frayh AR, Hasnain SM, Harfi HA (1989) Respiratory allergy and aeroallergen in Saudi Arabia. Journal of Allergy and Clinical Immunology 83(1): 198

6. Frayh AR, Sedairy S, Hasnain SM (1989) House dust allergens in two cities of Saudi Arabia. World Conference on Lung Health Supplement 141(4): 427.

7. Frayh AR, Hasnain SM (1989) Prevalence of asthma and allergic rhinitis in Saudi Arabia. European Annals of Allergy and Clinical Immunology, p. 16.

8. Frayh AR, Hasnain SM (1990) Allergens in Saudi homes in Riyadh. Annals of Saudi Medicine 10(2): 228

9. Frayh AR, Gad MO, Al-Najjar A, Hasnain SM (1992) A comparative study of immediate skin test reactivity to inhalant allergens in asthmatic children of two different regions in Saudi Arabia. Annals of Saudi Medicine 12(5): 467-71.

10. Hasnain SM, Frayh AR, Suwaine A, Gad R, Harfi HA, et al. (1995) Allergenic implication of airborne ulocladium in Saudi Arabia. Grana 34: 70-76.

11. Frayh A, Hasnain SM, Gad MO, et al. (1999) Human Sensitization to
Prosopis Juliflora Antigen in Saudi Arabia. Ann Saudi Med 19(4): 331336.

12. Frayh AR, Shakoor Z, Gad MO, Hasnain SM (2001) Increased prevalence of asthma in Saudi Arabia. Annals of Allergy, Asthma and Immunology 86(3): 292-296.

13. Alaiya AA, Alsini HA, Gad Rab, Hasnain SM (2014) Protein profiles of indigenous and commercial extracts of amaranthus pollen for the diagnosis of allergy and asthma patients. World Applied Sciences Journal 32(12): 2354-2361.

14. Hasnain SM, Qassim A, Modaihsh, Mahjoub M, Frayh A (2016) Airborne weed pollen in relation to allergic rhinitis in Riyadh, Saudi Arabia. British Journal of Medicine and Medical Research 14(7): 1-15.

15. Hasnain SM, Alsini H, Frayh A, Gad MO, Alaiya A (2016) Amaranthus pollen allergens: Protein diversity and impact on allergy diagnosis. International Journal of Chemical, Environmental and Biological Sciences (IJCEBS) 4(1): 87-92.

16. Hasnain SM, Qassim A, Hasnain S, Frayh A (2016) Emerging status of asthma, Allergic rhinitis and eczema in the middle east. Journal Disease and Global Health 7(3): 128-136.

17. Frayh A, Shakoor Z, Hasnain SM (2016) Family history of atopy as a risk factor for childhood asthma and allergic disorders in Saudi Arabia. Journal of Disease and Global Health 8(1): 18-25.

18. Hasnain SM, Hasnain S, Frayh A (2016) Allergy and asthma: Prevalence and frequency of inhalant allergens in the middle east. Journal of Disease and Global Health 7(1): 1-13.

19. Hasnain SM, Qassim A, Alsini H, Alsobhi A, Mohanna F, et al. (2017) Impact of Indoor allergenic fungal spores in Saudi Arabia. International Journal of Recent Scientific Research 8(5): 16912-16916.

20. Hasnain SM, Qassim A, Frayh A (2017) Diagnosis of allergy: IgE mediated cross-reactions amongst selected asthma elicitors. Journal of Disease and Global Health 10(4): 111-122. 
21. Hasnain SM, Qassim A, Frayh A, Mehdar H, Sedairy S, et al. (2017) Allergic Implications of Bla g1 and Bla g2 Concentrations in Houses of Saudi Arabia. Journal of Disease and Global Health 10(1): 27-33.

22. Hasnain SM, Alsini H, Mohanna F, Frayh A, Rayes H, et al. (2017) Prevalence of Fel d1 Cat Allergen in homes in Saudi Arabia. Journal of Disease and Global Health 10(2): 58-66.
23. Hasnain SM, Qassim A, Alsini H, Frayh A, Mohanna F, et al. (2018) Indoor sensitizers of allergy and asthma in coastal and non-coastal regions of Saudi Arabia. International Research Journal of Medicine and Medical Sciences 6(4):113-119.

24. Hasnain SM, Alsini H, Qassim A, Frayh A, Mohanna F (2018) Quantification of house dust mites allergens in home of Saudi Arabia. International Review of Basic and Applied Sciences 6(12): 94-104.

For possible submissions Click below: 